\title{
Analysis of Students' Process Skills and Chemistry Learning Outcomes
}

\author{
Arif Sholahuddin \\ Faculty of Teacher Training and Education \\ Universitas Lambung Mangkurat \\ Banjarmasin, Indonesia \\ arif.science.edu@unlam.ac.id
}

\author{
Yasfi Shadriyah \\ Islamic Senior High School Darul Hijrah \\ Islamic Boarding School Darul Hijrah \\ Martapura, Indonesia \\ shadriyahyasfi@gmail.com
}

\begin{abstract}
Generally, teachers have implemented certain learning model without considering how the students are accustomed to the learning model. They often face difficulties to reach learning objective, including process skills optimally. This research aimed to describe the students' process skills and learning outcomes after they are involved in chemistry learning by using gradual inquiry learning through the steps of direct instruction, guided inquiry and free inquiry. This research implemented pretest-posttest pre-experimental design in grade 11 of SMA Negeri 1 Martapura. The research data were collected by using test, questionnaire, and observation. The finding showed that students perform the development in their process skills as well as learning outcome significantly. Guided inquiry is the most recommended model as its greatest performance in achieving learning outcome. In addition, students have given a good response to the implementation of gradual inquiry model. According to this finding, to implement inquiry learning model which requires thinking ability and self-learning, we have to consider the students' learning habitude and their characteristics to ensure how the learning will be started by direct instruction, guided inquiry or even free inquiry.
\end{abstract}

Keywords-Gradual Inquiry, Process Skills, Learning Outcomes, Student Response

\section{INTRODUCTION}

The 2013 Curriculum of Indonesia has been designed to train students various process skills, skills used by students to discover knowledge. The skills are reflected in the use of scientific approach that involves observing, questioning, exploring, associating knowledge and data acquired, and communicating activities the learning outcomes that constitute the part of process skills. Learning process with scientific approach aims to build the students' knowledge through a series of scientific activities based on fact or phenomena that can be explained with logic or certain reasoning.

Ausubel differentiated between learn to discover and learn to get. In learning to get, students just receive, so they just need to remember which in turn it can be easily forgotten. On the other hand, in learning to discover, concept is discovered by students by themselves. In discovering the concept, students associate new information with relevant concepts that is found in their cognitive structure so that the information can be meaningful and easily to recall [1].

Learning with a series of scientific activities will also give chance to students to develop their intellectual ability as the part of mental process, so students are not just pushed to master the knowledge, but they are encouraged to use their potential to acquire the knowledge. In the process of learning based on constructivism, students learn more by themselves and develop their creativity in acquiring a new understanding. Therefore, in order to enable students to use their potential optimally, their process skills should be developed. Involving process skills in learning can help students in learning science concepts [2], so that with the increasing of their process skills it is expected that their mastery of science concept also develops.

Process skills can be developed using inquiry learning. Inquiry-based learning can improve students' process skills significantly [3], [4] and [5]. Supporting the aforementioned finding, [6] report that correlation was found between inquiry learning and science process ability.

Gradual inquiry leaning model is learning model based on how much guidance or scaffolding is given by teacher gradually during learning. There are two inquiry steps, guided inquiry and free inquiry. In this research, before applying gradual inquiry, in the beginning step of the learning students used direct instruction strategy to train and accustom scientific activities in inventing knowledge. According to [7], how much guidance or scaffolding is given by teacher in the learning process really depends on the development level of students' intellectual. As learning strategy from direct instruction, guided inquiry to free inquiry draws the more decreasing of guidance or scaffolding.

Teacher's scaffoldings cause students to do and understand more things compared with the effect if students learn alone. It can help students to reach their zone of proximal development, so they can complete their learning assignments that should be finished. The scaffoldings can be hint, warn, stimulus, resolve problem to the learning steps, giving example or others to 
make students able to grow independently [1]. According to many researchers' findings [8], guided inquiry approach also provides more direction to students who may be poorly prepared to tackle inquiry problems without prompts and instruction because of lack of experience, knowledge, or because they have not reached the level of cognitive development required for abstract thought. The guidance provided by the instructor's questioning should provide that instruction and therefore lower student frustration levels while still maintaining a high level of intellectual challenge.

Many research conducts have been investigated to compare inquiry and non-inquiry approach such as [8], [9] with the separated students' group to investigate whether they are more effective than other in science learning. Conversely, this study implemented guidance level needed by the senior high school students while involving chemistry leaning process with inquiry model. This research showed the inquiry level applied subsequently. This research measured the learning outcome indicator and process skills as the effect of gradual inquiry learning process.

\section{METHOD}

Research design used in this study was One-Shot Case Study. The research samples were 30 students from class 11 of SMA Negeri 1 Martapura determined by cluster random sampling from other 6 intact classes.

This study was divided into three periods. At the first period, the students were taught using direct learning process. At the second period, the students were taught using guided inquiry, and at the third period, the students were taught using free inquiry with continuous learning materials starting from solubility and solubility product constant to colloid learning material.

Test was used to measure the students' learning outcome and process skills. There were also observation sheets to evaluate students' process skills, psychomotor skills, and affective aspect during learning. In addition, questionnaire was used to know the students' responses toward the implementation of learning model. All the instruments were evaluated in terms of its content validity by the experts. The whole questions had CVR score $=1$ (bigger than CVR minimum score that is 0, 99) indicated that the whole questions were valid. The reliability of the chemistry test was on the high category $(\mathrm{r}=0,76)$.

The collection of data was assisted by two teachers as observers during the research. The collected data were then analyzed descriptively.

\section{RESULTS}

Fig. 1 shows students' process skills after they were involved in inquiry learning process gradually. Students' skills tend to develop during involved learning process using guided inquiry model and tend to reduce during involved learning process using free inquiry model. The lowest students' process skill was defining variable operationally.

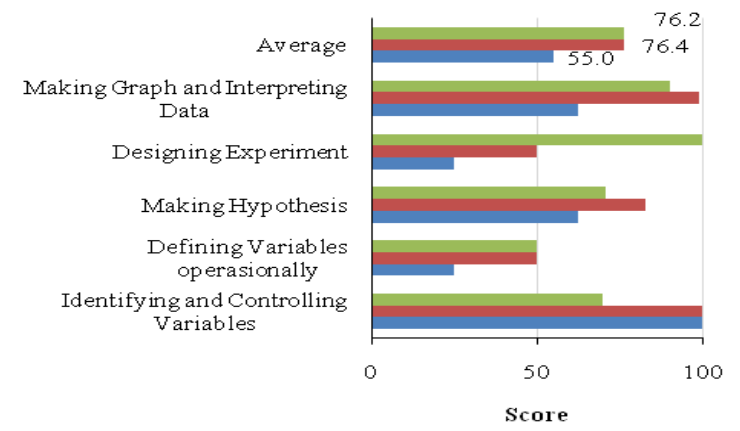

Fig. 1 Students' process skills during learning period to period; $₫$ direct instruction; aguided inquiry, free inquiry

Mean of the students' process skills during involved learning process was compared with final process skills shown on Table 1. The mean score of the students' skills during the learning process was 69.2 in good category, while the mean score of final test result was 75.2 in good category

TABLE I. STUDENTS' PROCESS SKILLS DURING AND AFTER LEARNING PROCESS

\begin{tabular}{|c|c|c|c|c|}
\hline \multirow[b]{2}{*}{ Process Skills } & \multicolumn{3}{|c|}{ Score } & \multirow[b]{2}{*}{ Category } \\
\hline & $\begin{array}{c}\text { Observation } \\
\text { during } \\
\text { learning }(O)\end{array}$ & $\begin{array}{c}\text { Test } \\
(T)\end{array}$ & $\begin{array}{c}\text { Average } \\
\quad(O, T)\end{array}$ & \\
\hline $\begin{array}{l}\text { Identifying and } \\
\text { controlling variables }\end{array}$ & 90.0 & 89.0 & 89.5 & Exellence \\
\hline $\begin{array}{l}\text { Defining variables } \\
\text { operasionally }\end{array}$ & 41.7 & 62.0 & 51.8 & Poor \\
\hline Making hypothesis & 72.0 & 63.0 & 67.5 & Moderate \\
\hline Designing experiment & 58.3 & 90.0 & 74.2 & Good \\
\hline $\begin{array}{l}\text { Making graph/table } \\
\text { and interpreting data }\end{array}$ & 83.9 & 72.0 & 77.9 & Good \\
\hline Average & 69.2 & 75.2 & 72.2 & Good \\
\hline
\end{tabular}

Criteria:

80-100 = Exellence; $70-79=$ good $; 60-69=$ moderate $; 0-59=$ poor

Fig. 2 shows the result of students' cognitive learning outcome in chemistry which includes solubility and solubility product constant to colloid concepts; the affective learning outcome which includes responding, valuing, organizing and characterizing; and the psychomotor learning outcome which includes indicators of using dropper drop, measuring cup and filter paper according to the laboratory activities that did them during the lesson 


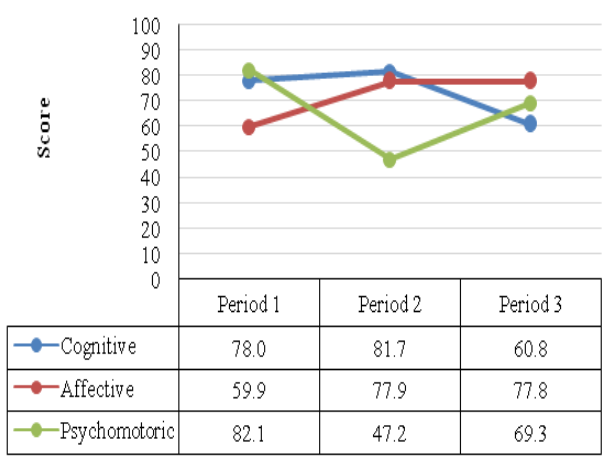

Fig.2 Students' learning outcome

Fig. 3 indicates that the majority of students, $82 \%$ responded positively to the application of this inquiry model gradually.

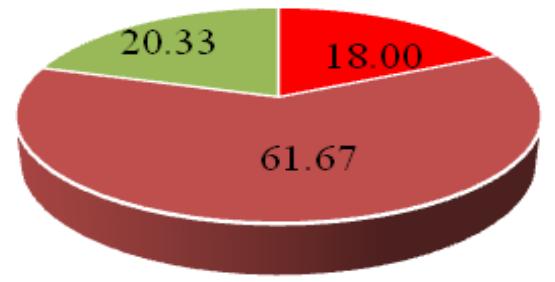

Fig. 3 Students' response to application of inquiry learning model gradually -very positive; - positive, $\square$ moderate response

Fig. 4. shows that most of the students like to follow learning with free inquiry model, followed by guided inquiry and direct instruction. However, based on Fig. 5, the students' learning model most suitable for the chemistry learning is guided inquiry.

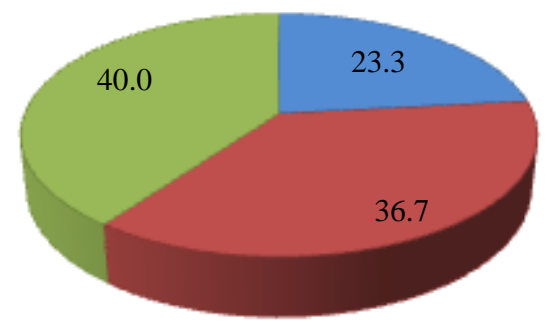

Fig. 4 Learning Model was preffered by students ๓direct instruction; - guided inquiry, $₫$ free inquiry

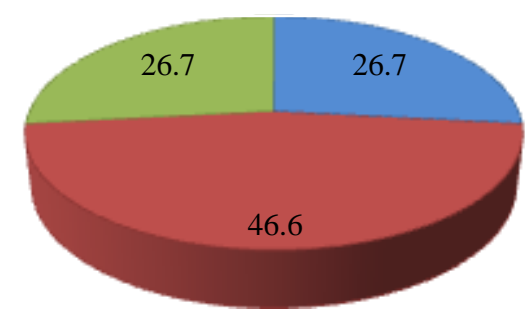

Fig. 5 Learning model was appropriate to chemistry learning =derect instruction; guided inquiry, free inquiry

\section{DISCUSSION}

\section{A. Process Skills}

Implementation of direct instruction model in the first learning period is intended to familiarize students in applying process skills to find concepts. The implementation of guided inquiry model has improved the students' process skill from the previous period i.e. learning with direct instruction model, then in the $3^{\text {rd }}$ period study which was with the free inquiry learning model where their process skills were relatively stagnant. These results illustrate that students are still experiencing learning difficulties using free inquiry with minimal teacher roles to develop process skills. Free Inquiry requires student self-reliance.

The students' process skill is used to define variables operationally. This result is in line with the findings of [10] that process skill indicator that junior or senior high school students master poorly was to make hypotheses and operational definitions. The operational definition is a definition of the research variables that reflects how to measure the certain variable. Students' skill in defining variables operationally is indicated by their ability to define how to measure a variable when something about research is described. For example, in the case of process skill test [11], the variable of evaporation number can be defined operationally in various ways e.g. the time it takes for a certain amount of liquid to vaporize, the volume of liquid evaporating over a period of time, or the time of the liquid evaporating within a certain time.

\section{Problem:}

Thibo wanted to show his friend that the size of the container affects the vapor speed of water, when heated.

(1) He prepares a container of the same type of material, but with varies of size.

(2) Each container is filled with the same amount of water.

(3) Each container is heated for 30 minutes with the same amount heat

(4) Next he measured the amount of water left in the container. 
How is the vaporization rate of water measured in this investigation?

A. By measuring the amount of water in each container after heating for 30 minutes.

B. By using different container sizes to boil water

C. By calculating the time it takes for water to boil on each container

D. By determining the difference between the initial and final water counts over a given time in the 30 minute range.

The scores of process skills, making definition variable operationally and designing experiment, which students acquire during learning, were lower than test scores. The scores were in contrast to other components in which the value of process skills were higher than the results of the process skill test (Table 1). On a written test of process skills, the choice of answers was available in the problem posed so that students did not need to define variables operationally themselves but simply to choose the right option. Meanwhile, according to Fig 1, the skill of designing experiment was the most successful when using direct instruction learning model. This case showed that procedural knowledge was difficult for students and required more detailed guidance and gradual training to master it.

Ref [12] found different results that students' learning outcomes and process skills using guided inquiry learning models were better than students who studied using the free inquiry model. This is because students learning using free inquiry models cannot adapt to learning with investigative activities without preparing them with a basic knowledge of investigation. Ref [13] explains if students are required to study like scientists, students must learn how to find. Inquiry learning requires some basic skills such as exploring information from various sources, discussing, and working in groups. Therefore, learning based on investigation or inquiry should be accustomed gradually consonant to students' cognitive development levels and skills. Many experts argue that inquiry instruction may not be the best approach for increasing science literacy, particularly for students who are not consonant to their cognitive development to meet the challenges it provides [14], [15].

If the students already had sufficient basic skills of inquiry, they would be able to conduct free inquiry even with more optimal results than guided inquiry. Free inquiry gives an opportunity to determine focus of problem to be studied and not limited to just what the teacher given. Ref [16] concluded that learning in a laboratory using free inquiry strategy improves student process skills more effectively than guided inquiry learning strategy.

In general, inquiry-based learning strategy has been proved able to prepare students' process skills. The students' process skills have increased after the students are engaging in inquiry-based learning activities. The greatest improvement are measuring skill, classifying/correlating skill and hypothesizing skill. The pretest and posttest scores for each indicator increased from 23 to 35,27 to 40 and 13 to 30 , respectively [5]. After the implementation of guided inquiry lab approach, students demonstrated a significant improvement in science literacy skills and process skills $4 \%$ and $2 \%$ greater gains, respectively compare to traditional labs curriculum [8].

\section{B. Learning Outcomes}

\section{1) Cognitive}

Fig. 2 present the students' cognitive learning outcomes after participating in direct instruction, namely 78 or good category. Their learning outcome after learning with guided inquiry was 82 or excellence, while after free inquiry decreased to 60 or medium category. This findings are in line with other studies that improvement in learning outcomes using inquiry learning is higher than using free inquiry models [17], [18].

Teacher's guidance to focus students on learning materials during direct instruction and guided inquiry resulted wellorganized materials to be learned. It is hypothesized to help students to construct their knowledge and memories easily [19]. It caused their average score of cognitive learning outcomes after participated guided inquiry learning higher than their average score in free inquiry learning.

In free inquiry learning strategy, the students were expected to find and solve problems themselves. During this study, they faced difficulties to find the problems to be solved, so they were confused. Learning with guidance will be more effective than learning without guidance because the former can minimize students' tendency to get negative results as a result of misconception or incomplete knowledge [19]. Using similar strategies in junior high school students showed that cognitive learning outcomes in free inquiry strategy achieved the lowest average scores than in guided inquiry strategy or in expository strategy.

\section{2) Psychomotor}

The results showed that students were able to achieve the best psychomotor skills when the learning applied direct instruction model. In the first period, the teacher demonstrated laboratory skills to students before the experiment began, then students followed according to this instruction. It was proved able to reach students' psychomotor skills to excellence category. This achievement was higher than the next learning period, guided inquiry or free inquiry model.

At the second period of learning, guided inquiry learning, teacher reduced her guidance or scaffolding. The teacher no longer demonstrated experiments in front of the class, but only gave guidance to students through worksheet and monitored their learning activities. By teacher's guidance, the students tried to find chemistry concept of common ion effect in precipitation through experimenting. However, only some students were involved actively in laboratory experiment. Consequently, it caused students' psychomotor skills score decrease to 47 or poor category. The students' psychomotor skills during the second period of learning were lower than the previous period. These findings also prove that procedural 
knowledge requires direct instruction strategies for students to achieve optimal learning outcomes.

At the third period, the students were required to learn independently while the teacher acts as a facilitator in the classroom. Motivation and guidance from teachers were not or minimally given during the experiment. Students were asked to design experiments and gather information as much as possible from the handbook or the internet by discussing in their groups. Only two groups were ready with the gathered information to begin chemistry experiment while the others, four groups, only imitated their friends work and they did not know the treatment and chose to ask the teacher or friends in spite of seeking information from other sources. This proves that generally students are ready to learn independently although facilities for obtaining information such as chemistry books and Wi-Fi networks have been provided by schools. Nevertheless, through free inquiry learning all the students become more active and more motivated than the second period of learning so that the score of students' psychomotor skills achieved 69 or in moderate category.

The different finding has been reported that there was no difference in psychomotor learning outcomes between students taught with guided inquiry and those taught with free inquiry [18], and psychomotor achievement is higher in guided inquiry based learning than in free inquiry-based learning [21]. Ref [18\} argue that laboratory skills of students will be seen if students are involved in experimental activity. Otherwise, if the students are passive, laboratory skills will decrease as well as their psychomotor learning outcomes. Providing guidance in the form of a more elaborate work procedure will minimize the decrease in psychomotor learning outcomes as it improves student activity during experimenting.

Students who have been trained of inquiry activities will have basic knowledge and skills to conduct investigation independently. When teacher's guidance is gradually reduced the students' ability to do inquiry activities will increase. Otherwise, when the teacher's guidance is reduced suddenly or not given at all, it will tend to give a negative results because students are not motivated to follow the learning activities due to their incomplete knowledge and skills. Ref. [22] suggested that students' learning motivation with the application of guided inquiry method is higher than free inquiry. It is in contrary with this research which found that students 'psychomotor learning outcomes during the experimental activities in free inquiry model is higher than guided inquiry.

\section{3) Affective}

Students' affective learning outcomes improved after a gradual inquiry learning model was applied. During application of direct instruction model, the students' affective learning result was the lowest of subsequent periods, achieving 60 or in moderate category. At the second period, guided inquiry learning, the students' attitude increased from the previous period. The learning model requires students to be more active in discussing with their group. By discussion students learn to defend and accommodate opinions of others. It is one of the factors that make affective scores increases from previous periods. The average score of affective learning outcomes at the second period was 78 or in good category. There was no significantly different in affective learning outcomes between learning chemistry using guided inquiry model and free inquiry model. The finding is supported by [23], that there was no significant difference in students' psychomotor as well as affective learning outcomes when they were taught using a guided inquiry and free inquiry learning strategy.

The inquiry learning model gives opportunity to students to develop conceptual understanding freely through inquiry activities in their group. Discussion activities in preparing or interpreting data as steps of investigation activities increase students' social interaction. Students who are active in the discussion have reached the responding stage of affective domain meanwhile students are required to organize (organizing level of affective domain) when they have difference opinions to the others. Therefore, by teacher's guidance or not, the students' affective learning outcomes tend to be a positive.

Ref. [24] concludes that learning with the application of guided inquiry method is more effective to improve students' cognitive, psychomotor and affective learning outcomes than experimental method. Inductive strategies in guided inquiry method can increase students' interest to follow the learning, while deductive strategy in experimental method can reduce their curiosity because experimental method is just to prove the known theory.

Popham in Ref. [25] explains that affective domain determines the students' success in learning. Someone who has no interest in a particular lesson will find it difficult to achieve learning outcome optimally and vice versa. This research indicates that as the students' affective learning outcomes increase, psychomotor learning outcomes, process skills, and students' cognitive learning outcomes also tend to increase. Other researcher [26] requires 2 years of research to prove that there is a change in student attitudes during the study and their procedural knowledge between free inquiry models and guided inquiry.

This gradual application of inquiry model leads to full involvement of students in learning process that may produce the expected instructional effects. In addition, during engaging students in learning process, they seem enthusiastic and interact intensively with other students as well as teacher. It may provide an affective domain achievement including social skills. Ref. [9] found that relative to non-inquiry laboratory activities, inquiry instruction seemed to promote significantly more student cohesiveness in the classroom. Students cited numerous examples of a supportive environment, in which peers helped each other to find solutions and reason through problems, and showed respect for others' opinions. Meanwhile in the non-inquiry laboratory students offer 
examples related more to dividing work assignments than in working as a collective and supportive team.

Most of the students responded positively to the lesson by using gradual inquiry model. The students preferred the application of free inquiry models to the others. This indicated that the students enjoyed the freedom of expressing themselves in learning. However, for those who have no independent learning habits, free inquiry strategy is less appropriate, especially to achieve the standard of learning outcomes.

Based on the learning outcome data and students' responses in this research, the most appropriate learning model is guided inquiry. The students tend to choose guided inquiry as a model that is considered suitable for chemistry learning. By guided inquiry, students still have opportunity to seek their own knowledge under teacher's supervision that helps them to elaborate chemistry concepts.

Students who are given some kinds of guidance act more skillfully during the task, are more successful in obtaining topical information from their investigational practices, and score higher on tests of learning outcomes administered after the inquiry. These benefits are largely independent of the specificity of the guidance: even though performance success tends to increase more when more specific guidance is available, learning activities and learning outcomes improve as much with specific and nonspecific types of guidance. The effectiveness of guidance applies equally to children, teenagers, and adolescents [27]. The students' inquiry skills were significantly improved after they participated in the series of the inquiry learning activities. The students made significant progress in identifying causal relationships, describing the reasoning process, and using data as evidence. They showed slight improvement in evaluating explanations. This findings also indicate that teacher's support and coparticipation of more competent others have played a crucial role in students' achievement. Teachers have provided scaffolds through questioning, guiding, and modeling to support students' engagement of explanatory activities [28]. The findings of this research reveal that guided inquiry is the best strategy to facilitate senior high school students in chemistry learning. However, when the students have gained more experience in doing inquiry, they take more responsibilities for their own learning and teacher takes more role of facilitator.

\section{CONCLUSION}

The implementation of gradually inquiry model has achieved students' process skills as well as learning outcomes (understanding chemistry concept, affective and psychomotor skills) significantly. Students have given good responses to the implementation of gradually inquiry model. According to the research findings, guided inquiry is the most recommended model due to its greatest performance in achieving learning outcome. Inquiry learning should be applied gradually from full guidance to minimum guidance or free guidance in accordance with students' readiness.

\section{ACKNOWLEDGMENT}

The researchers thank to Head of Education Department, Ministry of Education and Culture of the Republic of Indonesia and the Principal of SMAN 1 Martapura, who have facilitated this research.

\section{REFERENCES}

[1] R. E. Slavin, Educational Psychology Theory and Practice 8th edition, Pearson Education, Boston, 2006.

[2] R. W. Dahar dan A. Sumarna, Buku Materi Pokok Pengelolaan Pengajaran Kimia. Jakarta: Universitas Terbuka, 1986.

[3] F.R. Sullivan,"Robotic and science literacy: Thinking skills, science process skills and system understanding", Journal of Research in Science Teaching, vol. 45, no. 3, pp.373-394, 2008.

[4] H-K Wu and C. E Hsieh, "Developing sixth grader's inquiry-based skills to construct explanation in inquiry based learning environments". International Journal of Science Education, vol. 28, no. 11, pp. 12891313, 2006.

[5] P. Simsek and F. Kabanipar, "The effect of inquiry-based learning on elementary students' conceptual understanding of matter, scientific process skills and science attitude", Procedia Social and Behavioral Sciences, vol 2, pp. 1190-1194, 2010. Doi: 10.1016/j.sbspro.2010. 03.170

[6] A. Sulistyorini \& R. Permatasari. 2015. Pembelajaran Inkuiri dan Kaitannya dengan Keterampilan Proses Sains. Prosiding Seminar Nasional Pendidikan Sains Tahun 2015, Surabaya. Hlm: 692-699

[7] A. A. Carin, Teaching through discovery, $7^{\text {th }}$ edition, New York: Macmillan, 1993.

[8] C. Gormally, P. Brickman, B. Hallar, and N. Armstrong, "Effects of Inquiry-based Learning on Students' Science Literacy Skills and Confidence,"International Journal for the Scholarship of Teaching and Learning: vol. 3: no. 2, 2009, https://doi.org/10.20429/ijsotl.2009 .030216

[9] J. W. Stephen and J. F. Barry, "learning environment, attitudes and achievement among middle-school science students using inquirybased laboratory activities", Res Sci Educ, vol. 38, pp. 321-341, 2008, DOI 10.1007/s11165-007-9052-y

[10] A. Sholahuddin, Profil Keterampilan Proses Sains Terpadu Siswa SMP Negeri dan SMA Negeri Kota Banjarmasin, Prosiding, Semarang: Jurusan IPA Terpadu, April 2015, ISBN 978-602-1034-12-5 pp. 866875 .

[11] K. M. M. Monica, Development and Validation of A Test of Integrated Science Process Skills for The Futher Education and Training Learners, Dissertation, South Africa: Faculty of Natural and Agricultural Sciences Pretoria University, 2005, Unpublished.

[12] N.P. Maherni, I.W. Muderawan, and I.N. Tika, "Studi komparasi model pembelajaran inkuiri terbimbing dan model pembelajaran inkuiri bebas terhadap hasil belajar dan keterampilan proses sains siswa pada pembelajaran sains SMP”, e-Journal Program Pascasarjana Universitas Pendidikan Ganesha, vol. 4. pp.1286-1296, 2014.

[13] P. A. Kirschner, J. Sweller, J. and R. E. Clark, "Why minimal guidance during instruction does not work: An analysis of constructivist, discovery, problem based, experiential, and inquiry based teaching, Educational Phsychologist, vol. 41, no. 2, pp.75-86, 2006.

[14] F. H. Heppner, K. R. Kouttab, and W. Croasdale, "Inquiry: Does it favor the prepared mind? American Biology Teacher", vol. 68, no. 7, pp. 390-392, 2006.

[15] R. K. Yerrick, "Lower track science students' argumentation and open inquiry instruction". Journal of Research in Science Teaching, vol. 37, no. 8 , pp. $807-838,2000$.

[16] I. Damopolii, A. Hasan and N. Kandowangko, "Pengaruh strategi pembelajaran inkuiri bebas dimodifikasi dan kemampuan memecahkan masalah terhadap keterampilan proses sains mahasiswa pada praktikum fisiologi tumbuhan", Pancaran, vol 4, no.3, pp. 191-200, 2015. 
[17] S. Hajar, Perbandingan Hasil Belajar dan Kemampuan Berpikir Kritis Siswa antara Model Pembelajaran Inkuiri Bebas dan Inkuiri Terbimbing pada Materi Hukum Dasar Kimia untuk Siswa Kelas X MIA SMAN 1 Banjarmasin Tahun Ajaran 2014/2015. Banjarmasin: Universitas Lambung Mangkurat, Tidak dipublikasikan, 2015.

[18] Widyaningsih, S.Y, Haryono and S. Saputro, "Model MFI dan POGIL ditinjau dari aktivitas belajar dan kreativitas terhadap prestasi belajar", Jurnal Inkuiri, vol. 1 no. 3, pp. 266-275, 2012.

[19] F. T, Durso and K.A. Coggins, "Organized instruction for the improvement of word knowledge skills". Journal of Educational Psychology, vol. 83, pp. 108-112, 1991.

[20] A. Nuraini, Perbedaan Keberhasilan Model Pembelajaran Inkuiri Terbimbing dengan Model Pembelajaran Inkuiri Bebas pada Aspek Kognitif Peserta Didik. Bandung: Universitas Pendidikan Indonesia, 2013, Tidak dipublikasikan.

[21] Mulyono, Pembelajaran Biologi Berbasis Masalah Menggunakan Metode Inkuiri Terbimbing dan Inkuiri Bebas Termodifikasi Ditinjau dari Kreativitas dan Konsep Diri, Solo: Universitas Negeri Sebelas Maret, Solo, 2010. Tidak dipublikasikan.

[22] K. Budiasa, Viyanti, and I.D.P. Nyeneng, Perbandingan Metode Inkuiri Terbimbing dan Bebas Termodifikasi Terhadap Motivasi dan Hasil Belajar, Lampung: FKIP Universitas Lampung, 2013, Tidak dipublikasikan

[23] I. N. Handayani, and Hariyatmi, Perbedaan Hasil Belajar Menggunakan Strategi Pembelajaran Inkuiri Terbimbing dan Inkuiri Bebas dalam
Mata Pelajaran IPA Biologi Siswa Kelas VIII di SMP N 5 Klaten tahun ajaran 2012/2013. Surakarta: Universitas Muhammadiyah Surakarta, 2013, Tidak dipublikasikan.

[24] A. P. Rahayu, Ashadi and S. Sulistyo, Pembelajaran kimia menggunkana metode eksperimen dan guided inquiry ditinjau dari kemampuan matematis dan kreativitas siswa, Jurnal Inkuiri, vol. 3 no. $1,2014$.

[25] Kemendiknas, Pengembangan Perangkat Penilaian Psikomotorik, Jakarta: Direktorat Pendidikan Menengah Umum Depdiknas, 2008.

[26] I. Sadeh and M. Zion, "The development of dynamic inquiry performances within an open inquiry setting: a comparison to guided inquiry setting", Journal of Research in Science Teaching. vol. 46, pp. 1137-1160, 2009.

[27] W. Lazonder and R. Harmsen, "Meta-analysis of inquiry-based learning: Effects of guidance", Review of Educational Research, Month 201X, vol. XX, no. X, pp. 1-38, 2016, DOI: $10.3102 / 0034654315627366$.

[28] Hsin-Kai Wua and Chou-En Hsiehb, "Developing sixth graders' inquiry skills to construct explanations in inquiry-based learning environments", International Journal of Science Education, vol. 28, no. 11, pp. 1289-1313, 2006. 